\title{
A retrospective analysis of efficacy of systemic therapy in metastatic thyroid cancer
}

\author{
Metastatik tiroid kanserinde sistemik tedavi etkinliğinin retrospektif olarak değerlendirilmesi
}

\author{
Atakan DEMIR
}

\begin{abstract}
Objective: Thyroid cancer is the most common type of endocrine cancer. The current approaches in the systemic therapies of metastatic thyroid cancers are chemotherapy that is investigated in phase II clinical trials and tyrosine kinase inhibitors, investigated in phase III clinical trials. The aim of this study was to evaluate the efficacy of systemic therapies in metastatic thyroid cancer patients.

Materials and Methods: We investigated 57 patients retrospectively, diagnosed with thyroid cancer who were referred to Maslak Acibadem Hospital Medical Oncology Department between 2008-2015 and Umraniye Training and Research Hospital between 2016-2018. They had received systemic treatment due to the refractory profile to radioiodine therapy and metastatic thyroid cancer.

Results: Medical records of 57 patients with metastatic thyroid cancer, who were referred for systemic therapy were retrospectively analysed. $52 \%(\mathrm{n}: 30)$ of the cases were women and $48 \%$ (n:27) were men, and the mean age was 57.11 years. All patients was above the age of 18 . Of the patients, $59.8 \%$ (n:35) had well differentiated thyroid cancer, $29.8 \%$ (n:17) had medullary thyroid cancer, 5.3\% (n:3) had anaplastic thyroid cancer, 3.5\% (n:2) had poorly differentiated thyroid cancer and $1.8 \%$ (n:1) had medullarypapillary synchronous cancer. When first line systemic therapy was evaluated for all 57 patients, progression free survival (PFS) was found 4.25 and 6.33 months for chemotherapy and sorafenib, respectively (P:0.035). All cases were evaluated retrospectively for second line systemic therapy and PFS was 4.1 and 7.77 months for chemotherapy and sorafenib, respectively $(\mathrm{P}<0.001)$.

Conclusion: Tyrosine kinase inhibitors are used in the treatment of radioactive iodine-refractory differentiated thyroid cancers and medullary thyroid cancers. The effect of lenvatinib, sorafenib and vandetanib on progression-free survival in thyroid cancers is found to be superior to systemic chemotherapy. It was concluded that sorafenib is a systemic treatment option which can be preferred in terms of efficacy and toxicity profile in radioactive iodine refractory well-differentiated thyroid cancer especially in our country.
\end{abstract}

Keywords: Thyroid, Cancer, Sorafenib

Atakan Demir( $\square)$

Medical Oncology Department, Maslak Acibadem Hospital, Maslak, Istanbul, Turkey

e-mail: atakandemir85@gmail.com

Submitted / Gönderilme: 22.09.2018

Accepted/Kabul: 14.12.2018
ÖZ

Amaç: Tiroid kanserleri, endokrin kanserleri içerisinde en s1k görülen kanserdir. Metastatik tiroid kanserlerinin sistemik tedavisinde güncel yaklaşımlar faz II çalışması olan kemoterapi ve faz III çalışması tirozin kinaz inhibitörleridir. Çalışmamızda, metastatic tiroid kanserli hastalarda sistemik tedavilerin etkinliğini belirlemeyi hedefledik.

Gereçler ve Yöntemler : Maslak Acıbadem Hastanesi Tibbi Onkoloji Kliniği'ne 2008 ile 2015 yılları arasında ve 2016 ile 2018 yılları arasında Sağlık Bakanlığı Sağlık Bilimleri Üniversitesi Ümraniye Eğitim ve Araştırma Hastanesi Tıbbi Onkoloji Kliniği'ne gelen ,hem metastaz gelişmesi, hem de radyoaktif iyot tedavisine refrakter olması nedeniyle sistemik tedavi amacıyla yönlendirilmiş olan 57 metastatik tiroid kanseri olan hastaların dosyalar1 retrospektif olarak analiz edildi.

Bulgular : Hastaların, \%52'si (30 hasta) kadın, \%48'i (27 hasta) erkek, yaş ortalaması 57,11, ve tamamı 18 yaşın üzerinde idi. Hastaların, \%59,8'i (35 hasta) iyi diferansiye tiroid kanseri, \%29,8'i (17 hasta) medüller tiroid kanseri, \%5,3’ü (3 hasta) anaplastik tiroid kanseri, \% 3,5'i ( 2 hasta) az diferansiye kanseri ve $\% 1,8$ 'i ( 1 hasta) medüller-papiller senkron kanseri idi. Birinci seri sistemik tedavi yanıtı tüm 57 olguda değerlendirildiğinde progresyonsuz sağ kalım (PFS) süresi kemoterapi ve sorafenib için sirasiyla 4,25 ve 6,33 ay olarak tespit edildi (P:0.035). İkinci seride toplam 57 hasta dosyas1 retrospektif olarak değerlendirildi ve PFS, kemoterapi alan ve sorafenib kullanılan hastalarda 4,1 ve 7,77 ay olarak bulundu $(\mathrm{P}<0.001)$.

Sonuç: Radyoaktif iyot tedavisine refrakter olarak diferansiye tiroid kanserleri ve medüller tiroid kanserleri tedavisinde tirozin kinaz inhibitörü kullanılmaktadır. Tiroid kanserlerinde lenvatinib, sorafenib ve vandetanibin progresyonsuz sağkalım üzerine olan etkisi sistemik kemoterapiden üstün bulunmuştur. Özellikle, ülkemizde olmak üzere radyoaktif iyod tedavisine refrakter iyi diferansiye tiroid kanserlerinde sorafenib, etkinlik ve toksisite profili açısından tercih edilebilecek bir sistemik tedavi seçeneğidir. Anahtar kelimeler: Tiroid, Kanser, Sorafenib

\section{Introduction}

Thyroid cancer is the most common type of endocrine cellderived cancer. Incidence of thyroid cancer increases with 
increasing age due to the various environmental and genetic factors. When considering all age groups, average incidence of thyroid cancer is $6.5 \%$ in women and $5.4 \%$ in men [1]. In general, about $75 \%$ of malignant thyroid tumours are presented as papillary thyroid cancer and $13 \%$ as follicular thyroid cancer, while the other types of thyroid cancer occur as medullary thyroid cancer by $7-8 \%$, and to a lesser extent, as anaplastic (undifferentiated) thyroid cancer [2]. Recently, there have been some changes in the incidence order of thyroid cancer and particularly, micropapillary variant has been started to be observed more commonly [3]. In papillary thyroid cancers, the presence of RAS oncogene and p21 are associated with higher frequency of lymph node involvement, whereas the presence of GSalpha mutation is more commonly associated with distant metastasis [4]. Administration of radioactive iodine is important in the treatment of differentiated thyroid cancers [3]. External radiotherapy is also recommended in patients aged over 45 years who have papillary thyroid cancer with a large mass and a large volume load after surgery [5]. Most recent approaches in medication therapy of thyroid cancers are chemotherapy, which is under phase II investigations, and tyrosine kinase inhibitors, for which are under phase III investigations [6]. A mitogen-activated protein kinase (MAPK) and phosphoinosidite 3-kinase (PI3K)-AKT the mammalian target of rapamycin (mTOR) are active growth pathways in thyroid cancer; in addition, BRAF V 600 E mutation is tested positive in $40 \%$ of primary cancers and $60-70 \%$ of metastatic cancers. RAS family is more active in follicular thyroid cancer, while rearranged during transfection (RET) pathway is more active in medullary thyroid cancer [7]. Most commonly used tyrosine kinase inhibitors are lenvatinib, sorafenib, vandetanib and cabozantinib [8]. In our current study, we evaluated the patients who received sorafenib, doxorubicin, cisplatin, cisplatin-doxorubicin, cisplatin-etoposide, carboplatinpaclitaxel and other therapies. We aimed to determine the efficacy of systemic treatment especially in patients with metastatic thyroid cancer.

\section{Materials and Methods}

A retrospective evaluation was conducted for a total of 57 patients with complete thyroid cancer. Data were collected and evaluated regarding patient age, gender, age at cancer diagnosis, time from first diagnosis to systemic treatment. Fluro-D-glucose-positron emission tomography/computed tomography (FDG-PET/CT), magnetic resonance
(MR), computed tomography (CT), ultrasonography (USG) imagings, serum calcitonin, serum thyroglobulin, carcinoembryonic antigen (CEA) markers and histological cancer types were evaluated for progression free survival (PFS) time analysis. Patients were grouped according to the treatments they received. Also patients who received chemotherapy were grouped separately according to chemotherapy regimen. The study was approved by the Institutional Ethics Committee (No: 2018-17/17) and performed in accordance with the Declaration of Helsinki.

\section{Statistical Analysis}

Statistical analyses were performed using SPSS 20.0 software (SPSS, Inc., Chicago, IL, USA). IBM SPSS version 20 ( SPSS, Inc., Chicago, IL,USA) was used for statistical analyses. Descriptive statistical analyses (mean, median, minimum, maximum, standard deviation) were performed. Demographic data were presented as minimum, maximum, \pm standard variation. Survival data were analysed using Kaplan-Meier curves. Stastistical analysis was performed using log-rank test. A P value of $<0.05$ was considered to be stastistically significant.

\section{Results}

Medical records of 57 patients with metastatic thyroid cancer, referred for systemic therapy were retrospectively analysed. 52\% (n:30) of the cases were women and 48\% $(\mathrm{n}: 27)$ were men, and the mean age was 57.11 years. 59.8\% (n:35) of the cases were diagnosed with well differentiated thyroid cancer, $29.8 \%$ (n:17) with medullary thyroid cancer, 5.3\% (n:3) with anaplastic thyroid cancer, 3.5\% (n:2) with poorly differentiated thyroid cancer and $1.8 \%$ (n:1) with medullary-papillary cancer (Table 1). Response to first line systemic therapy was evaluated in 57 patients. 35 of these patients were diagnosed with differentiated thyroid cancer. $28.1 \%$ of the patients with thyroid cancer received treatment with doxorubicin, $28.1 \%$ with cisplatin-doxorubicin, $10.5 \%$ with cisplatin-etoposide, 14\% with carboplatin-paclitaxel and $10.5 \%$ with sorafenib (Table II). Mean progressionfree survival (PFS 1) was 4.25 months in patients treated with first line chemotherapy and 6.33 months in patients treated with sorafenib (P:0.035) (Table III). For the second line systemic therapy, a total of 57 patient records were retrospectively evaluated. $1.8 \%$ of the cases received treatment with doxorubicin, $8.8 \%$ with cisplatin, $54.4 \%$ with sorafenib, $7 \%$ with cisplatin-doxorubicin, $12.3 \%$ with 
carboplatin-paclitaxel, $5.3 \%$ and $10.5 \%$ with other therapy (Table IV). PFS among patients with thyroid cancer who received chemotherapy was 4.1 months, while treatment with sorafenib resulted in a PFS of 7.77 months $(\mathrm{P}<0.001)$ (Table V). Initial thyroid surgery was total thyroidectomy in $94 \%$ of the patients (Table VI).

Table I. Histopathological subtypes of thyroid cancer

\begin{tabular}{|l|l|l|}
\hline Subtypes of thyroid cancer & $\begin{array}{l}\text { Frequency } \\
(\mathrm{n}=57)\end{array}$ & $\begin{array}{l}\text { Percent } \\
(\%)\end{array}$ \\
\hline Classical papillary & 20 & $35.1 \%$ \\
\hline Tall cell & 1 & $1.8 \%$ \\
\hline Follicular & 5 & $8.8 \%$ \\
\hline Hurthle & 3 & $5.3 \%$ \\
\hline Medullary & 17 & $29.8 \%$ \\
\hline Anaplastic & 3 & $5.3 \%$ \\
\hline Follicular variant of papillary & 2 & $3.5 \%$ \\
\hline Insular follicular variant of papillary carcinoma & 3 & $5.3 \%$ \\
\hline Poorly differentiated & 2 & $3.5 \%$ \\
\hline Medullary and Papillary & 1 & $1.8 \%$ \\
\hline Total & 57 & $100.0 \%$ \\
\hline
\end{tabular}

Table II. Surgery types

\begin{tabular}{|l|l|l|}
\hline Surgery types & $\begin{array}{l}\text { Patients } \\
(\mathbf{n}=\mathbf{5 7})\end{array}$ & $\begin{array}{l}\text { Percent } \\
(\mathbf{\%})\end{array}$ \\
\hline Total & 54 & $94.7 \%$ \\
\hline Subtotal Neck Dissection & 2 & $3.5 \%$ \\
\hline No surgery & 1 & $1.8 \%$ \\
\hline Total & 57 & $100.0 \%$ \\
\hline
\end{tabular}

Table III. First-line agents and administration frequencies

\begin{tabular}{|l|c|c|}
\hline First-line agents & Frequency & Percent (\%) \\
\hline Doxorubicin & 16 & 28.1 \\
\hline Cisplatin & 5 & 8.8 \\
\hline Sorafenib & 6 & 10.5 \\
\hline Cisplatin Doxorubicin & 16 & 28.1 \\
\hline Carboplatin Paclitaxel & 8 & 14.0 \\
\hline Cisplatin Etoposide & 6 & 10.5 \\
\hline Total & 57 & 100.0 \\
\hline
\end{tabular}

Table IV. Second-line agents and administration frequencies

\begin{tabular}{|l|c|c|}
\hline Second-line agents & Patients & Percent (\%) \\
\hline Doxorubicin & 1 & 1.8 \\
\hline Cisplatin & 5 & 8.8 \\
\hline Sorafenib & 31 & 54.4 \\
\hline Cisplatin Doxorubicin & 4 & 7.0 \\
\hline Carboplatin Paclitaxel & 7 & 12.3 \\
\hline Vandetanib & 3 & 5.3 \\
\hline OTHER CT & 6 & 10.5 \\
\hline Total & 57 & 100.0 \\
\hline
\end{tabular}

Table V. Progression-free survival (PFS) in first-line therapy

\begin{tabular}{|l|l|l|}
\hline First-line therapy & Patients & Mean (months) \\
\hline Doxorubicin & 16 & 3.88 \\
\hline Cisplatin & 5 & 3.00 \\
\hline Sorafenib & 6 & 6.33 \\
\hline Cisplatin Doxorubicin & 16 & 4.06 \\
\hline Carboplatin Paclitaxel & 8 & 4.75 \\
\hline Cisplatin Etoposide & 6 & 4.00 \\
\hline Total & 57 & 4.25 \\
\hline
\end{tabular}

Table VI. Progression-free survival (PFS) in second-line therapy

\begin{tabular}{|l|l|l|}
\hline Second-line therapy & Patients & Mean (months) \\
\hline Doxorubicin & 1 & 5.00 \\
\hline Cisplatin & 5 & 4.20 \\
\hline Sorafenib & 31 & 7.77 \\
\hline Cisplatin Doxorubicin & 4 & 3.00 \\
\hline Carboplatin Paclitaxel & 7 & 4.14 \\
\hline Vandetanib & 3 & 3.33 \\
\hline OTHER CT & 6 & 3.50 \\
\hline Total & 57 & 5.95 \\
\hline
\end{tabular}

\section{Discussion}

The efficacy of tyrosine kinase inhibitor in patients with thyroid cancer is the mainstay of our treatment algorithm. A study conducted with doxorubicin for the treatment of metastatic thyroid cancer in 30 patients showed partial and stable responses in three-fifths of patients who histologically diagnosed with medullary carcinoma, one-third of patients with papillary carcinoma and two-fifths of patients with Hurthle cell carcinoma [9].

A randomised evaluation was conducted for efficacy and toxicity of doxorubicin alone and combination of cisplatin and doxorubicin in patients with advanced thyroid carcinoma. 92 patients were included, of which 84 were evaluated. Histological classification was made according to Eastern Cooperative Oncology Group (ECOG) performance status and metastatic sites. Forty one patients received doxorubicin as a single agent and seven patients (17\%) showed partial response. Forty-three patients received combination therapy resulting in five complete and six partial responses (combined response rate, 26\%). This difference was not significant for overall response rate $(\mathrm{P}>0.1)$. Four of five patients who showed complete response survived for more than 2 years. None of the patients with partial responses survived for more than 2 years. Lifethreatening toxicities caused by chemotherapy occurred in five patients treated with drug combination and two patients treated with doxorubicin alone. 
Moreover, side effects were higher with the combination therapy [10]. In a phase II study which included all thyroid cancers treated with epirubicin and carboplatin, 1 patient achieved complete response and 5 patients achieved partial response [11]. In the present study, mean PFS 1 was 4.25 months in subjects receiving chemotherapy and 6.33 months in subjects receiving tyrosine kinase inhibitor during first-line therapy of thyroid cancer, while PFS 2 was 4.1 months in subjects receiving chemotherapy and 7.77 months in subjects receiving tyrosine kinase inhibitor during second-line therapy. Abramson et al. conducted a study on sorafenib therapy in 30 patients with thyroid cancer, of which 27 were diagnosed with differentiated thyroid cancer, and found a clinical benefit rate of $77 \%$, partial response rate of $23 \%$ and stable disease rate of $53 \%$, while the mean time to relapse of metastatic disease was 18 months [12]. In another phase II study of sorafenib in 41 patients with papillary thyroid cancer, Kloos et al., found a clinical benefit rate of $56 \%$, partial response rate of $15 \%$ and stable disease rate of $41 \%$, and reported the mean time to relapse of metastatic disease as 15 months [13]. In efficacy assessment of sorafenib in our study, time to relapse of metastatic disease was found to show a statistical benefit $(\mathrm{P}<0.035)$ (Figure 1) at 6.33 months during first-line therapy and also found to be statistically significant $(\mathrm{P}<0.001)$ (Figure 2) at 7.77 months during second-line therapy with sorafenib. A phase III study conducted for radioactive iodine refractory metastatic thyroid cancers, for which sorafenib was approved and $92 \%$ of which consisted of differentiated thyroid cancer showed a median disease-free survival of 10.8 months and 5.8 months in sorafenib and placebo groups, respectively ([HR] 0.59\% 95\% CI 0.45-0.76; $\mathrm{P}<0.0001$ ) [14]. The most important reason for difference in treatment response in the present study compared to other studies is the delayed treatment approval of tyrosine kinase inhibitors and the requirement of previous use of chemotherapy by Social Security Institution. In SELECT study, a phase III trial of lenvatinib, median PFS in radioactive iodine-refractory metastatic thyroid cancer was 18.3 months, which is about two times longer than PFS achieved with sorafenib [15]. This study has some limitations. This study represents a trial which evaluated the effects of tyrosine kinase inhibitors and conventional chemotherapy on thyroid cancer in a population cohort of 57 patients without a control group. It is a two centre study conducted with a small sample size. There is a possibility for bias in results obtained; this was a retrospective study and there is a potential for selection bias during retrospective data collection process. Although, we recorded the detailed data, a prospective study would provide a better evaluation for tyrosine kinase inhibitors and conventional chemotherapy in patients with thyroid cancer. Therefore, performed evaluations must be conducted in a larger patient group.

In conclusion, standard treatment for thyroid cancer is multikinase inhibitors. While, a tyrosine kinase inhibitor called vandetanib and a multikinase inhibitor called lenvatinib are among the standard treatments in medullary thyroid cancer, these are not authorised and used in our country because of the challenges in reimbursement in Turkey. Therefore, the best treatment in radioactive iodinerefractory metastatic differentiated thyroid cancer is a tyrosine kinase inhibitor called sorafenib.

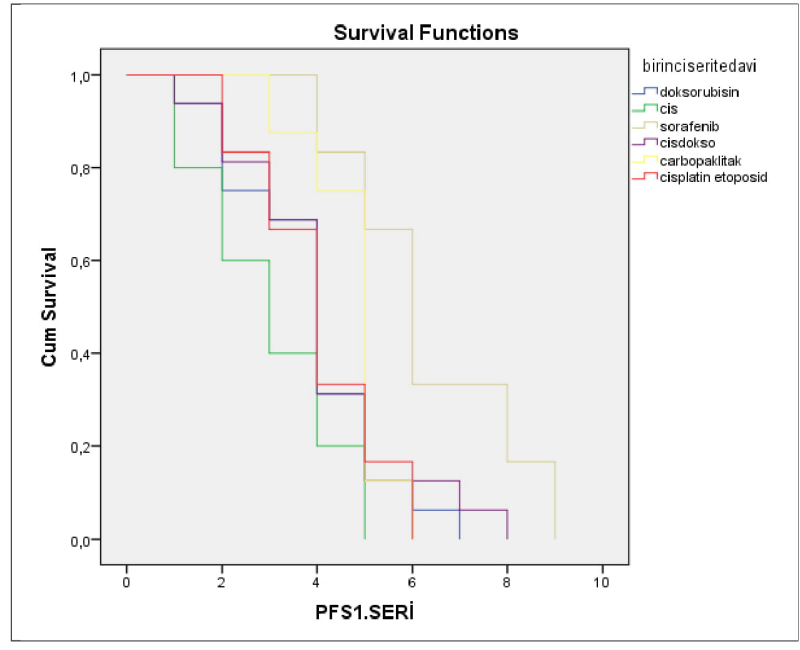

Cis: Cisplatin, cisdokso: Cisplatin -Doxorubicin, Carbopaklitak: Carboplatine- Paclitaxel

Figure 1. 1st progression free survival (PFS) time

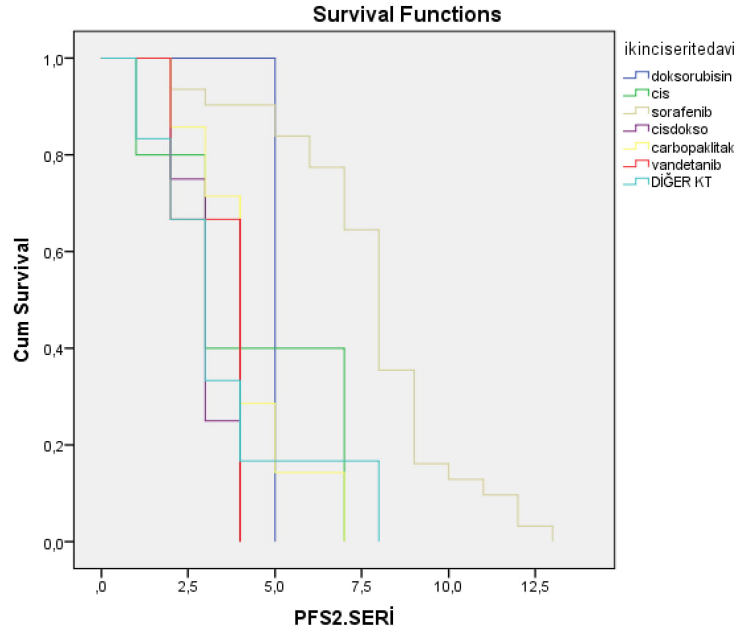

Cis: Cisplatin, cisdokso: Cisplatin -Doxorubicin, Carbopaklitak: Carboplatine- Paclitaxel

Figure 2. 2nd progression free survival (PFS) time 


\section{References}

1. Shah JP. Thyroid carcinoma: Epidemiology, histology, and diagnosis. Clin Adv Hematol Oncol 2015; 13(4 Suppl 4): 3-6.

2. Brown RL, De Souza JA, Cohen EE. Thyroid cancer: Burden of illness and management of disease. J Cancer 2011;2:193199. doi: https://doi.org/10.1530/ERC-16-0372.

3. Pacini F, Castagna MG, Brilli L, Pentheroudakis G. Thyroid cancer: ESMO Clinical Practice Guidelines for diagnosis, treatment and follow-up. Ann Oncol 2012;23 (suppl 1): vii110-9. doi.org/10.1093/annonc/mds230.

4. Barut F. Tiroid kanserlerinin patolojisi. Turkiye Klinikleri J Med Oncol-Special Topics 2017;10:10-2.

5. Cooper DS, Doherty GM, Haugen BR, et al. Revised American Thyroid Association management guidelines for patients with thyroid nodules and differentiated thyroid cancer. Thyroid. 2009 ;19:1167-214. doi: 10.1089/ thy.2009.0110.

6. Albero A, Lopéz JE, Torres A, et al. Effectiveness of chemotherapy in advanced differentiated thyroid cancer: a systematic review. Endoc Relat Cancer 2016;23:R71-84. doi: 10.1530/ERC-15-0194.

7. Kormaz T, Er Ö. Tiroid kanserlerinde tirozin kinaz inhibitör tedavisi, kemoterapi ve gelecekteki olası tedaviler. Turkiye Klinikleri J Med Oncol-Special Topics 2017;10:50-5.

8. Baran A., Yılmaz M. Tiroid kanserlerinde kemoterapi ve hedefe yönelik tedaviler. Türkiye Kanserle Savaş Vakfı Kanser Gündemi Tiroid Kanseri 2015;3/3:62-4.
9. Gottlieb JA, Hill CS Jr. Chemotherapy of thyroid cancer with adriamycin. Experience with 30 patients. N Eng Med J 1974;290:193-7. doi:10.1056 /NEJM 197.401.242900404

10. Shimaoka K, Schoenfeld DA, DeWys WD, et al. A randomized trial of doxorubicin versus doxorubicin plus cisplatin in patients with advanced thyroid carcinoma. Cancer 1985;56:2155-60. doi: 10.1002/10970142(19851101)56:9<2155.

11. Matuszczyk A, Petersenn S, Voigt W, et al. Chemotherapy with paclitaxel and gemcitabine in progressive medullary and thyroid carcinoma of the follicular epithelium. Horm Metab Res 2010;42:61-4. doi: 10.1055/s-0029.123.8294.

12. Abramson V, Troxel AB, Nellore A, et al. Phase II trial of sorafenib in advanced thyroid cancer. J Clin Oncol 2008;26:4714-9. doi: 10.1200/JCO.2008.16.3279.

13. Kloos RT, Ringel MD, Knopp MV, et al. Phase II trial of sorafenib in metastatic thyroid cancer. J Clin Oncol 2009;27:1675-84. doi: 10.1200/JCO.2008.18.2717.

14. Brose MS, Nutting CM, Jarzab B, et al. Sorafenib in radioactive iodine-refractory, locally advanced or metastatic differentiated thyroid cancer: a randomised, double-blind, phase 3 trial. Lancet 2014;384:319-28. doi: 10.1016/S01406736(14)60421-9.

15. Schlumberger M, Tahara M, Wirth LJ et al. Lenvatinib versus placebo in radioiodinerefractory thyroid cancer. N Engl J Med 2015;372:621-30. doi: 10.1056/NEJMoa1406470 